\title{
Anthracene-tagged UiO-67-MOF as highly selective aqueous sensor for nanoscale detection of arginine amino acid
}

\author{
Leila Mohammadi and Hamid Reza Khavasi*
}

Department of Inorganic Chemistry and Catalysis, Shahid Beheshti University, General Campus, Evin, Tehran 1983963113, Iran

E-mail: khavasihr@gmail.com 


\section{Experimental Section}

1. General Methods. The organic ligand 4,4'-biphenyldicarboxylic acid (BPDC) and the $\mathrm{ZrCl}_{4}$ were purchased and used without further purification from commercial suppliers (Sigma-Aldrich, Alfa Aesar, TCI, and others). Fourier-transform infrared (FT-IR) spectra $\left(4000-400 \mathrm{~cm}^{-1}\right)$ were collected in the solid state on a BOMEM- MB102 spectrometer using potassium bromide pellets. Powder X-ray diffraction (PXRD) experiments were performed on a Stöe StadiVari $\theta / \theta$ powder X-ray diffractometer equipped with a graphite monochromator and $\mathrm{Cu}-\mathrm{K} \alpha$ at $50 \mathrm{kV}, 50 \mathrm{~mA}$. Thermogravimetric analysis (TGA) was carried out. under a continuous air flow and recorded on a SDT Q600 V20.9 Build 20 thermogravimetric analyzer with a heating rate of $20{ }^{\circ} \mathrm{C}$ per min $\left(25-900^{\circ} \mathrm{C}\right)$. NMR spectra were recorded on a Brüker DPX-300 spectrometer at $300 \mathrm{MHz}$ for ${ }^{1} \mathrm{H}$ NMR and data for ${ }^{1} \mathrm{H}$ NMR are collected in $\mathrm{CDCl}_{3}$ as follows: chemical shift (ppm), multiplicity (s, singlet; d, doublet; t, triplet; q, quarter; m, multiplet), coupling constant (Hz), integration referenced to the appropriate solvent peak or $0 \mathrm{ppm}$ for TMS. The dinitrogen $\left(\mathrm{N}_{2}\right)$ adsorption isotherm was measured at $77 \mathrm{~K}$ using a liquid- $\mathrm{N}_{2}$ bath. SEM images were taken on Hitachi SU 3500. UiO-67 MOF was prepared following reported procedures.[1].

\section{The list of synthesized linkers in this project.}<smiles>CC(=O)c1ccc(-c2ccc(C(C)=O)cc2)cc1</smiles>

$\mathrm{L}_{1}$<smiles>CC(=O)c1ccc(-c2ccc(C(C)=O)cc2[N+](=O)[O-])cc1</smiles>

$\mathrm{L}_{2}$<smiles>CC(=O)c1ccc(-c2ccc(C(C)=O)cc2N)cc1</smiles>

$\mathrm{L}_{3}$<smiles>Nc1cc(C(=O)O)ccc1-c1ccc(C(=O)O)cc1</smiles>

$\mathrm{L}_{4}$<smiles>O=C(O)c1ccc(-c2ccc(C(=O)O)cc2/N=C/c2ccccc2)cc1</smiles>

$\mathrm{L}_{5}$<smiles>O=C(O)c1ccc(-c2ccc(C(=O)O)cc2/N=C/c2cccc3ccccc23)cc1</smiles>

$\mathrm{L}_{6}$<smiles>O=C(O)c1ccc(-c2ccc(C(=O)O)cc2/N=C/c2c3ccccc3cc3ccccc23)cc1</smiles>

$\mathrm{L}_{7}$ 


\section{Linker Preparation $[\mathrm{S} 1, \mathrm{~S} 2]$}

3.1. Preparation of $4,4^{\prime}$-biphenyldicarboxylic dimethylester $\left(\boldsymbol{L}_{1}\right)$. In order to prepare the 4,4'biphenyldicarboxylic dimethylester, $1.5 \mathrm{~g}$ of the corresponding acid was dissolved using excess volume of thionyl chloride $(30 \mathrm{ml})$ and was refluxed under moisture-free conditions until the reaction mixture became homogeneous. The reaction mixture was cooled to $0{ }^{\circ} \mathrm{C}$ and $90 \mathrm{ml}$ of methanol was slowly added. The whole solution was poured into ice cold water and the extraction was carried out with ethyl acetate, followed by drying with anhydrous $\mathrm{Na}_{2} \mathrm{SO}_{4}$ and evaporation of the solvent. The compound (4,4'biphenyldicarboxylic dimethylester) was recrystallized from ethanol. Yield: $1.45 \mathrm{~g}$ (95\%) of colorless crystalline powder. (Melting point $=210-212^{\circ} \mathrm{C}$ ). The characterization of the compound was carried out using NMR and FTIR studies: ${ }^{1} \mathrm{H}$ NMR $\left(300 \mathrm{MHz}, \mathrm{CDCl}_{3}\right) 3.97(6 \mathrm{H}, \mathrm{s}), 7.70(4 \mathrm{H}, \mathrm{d}), 8.13$ (4H, d); FT-IR $\left(\mathrm{KBr}\right.$ pellet, $\left.\mathrm{cm}^{-1}\right): 1682,1601,1396,1203,876,675,413$.

3.2. Preparation of dimethyl 2-nitrobiphenyl-4,4'-dicarboxylate $\left(\boldsymbol{L}_{2}\right)$. 4,4'-biphenyldicarboxylic dimethylester $(0.97 \mathrm{~g}, 3.58 \mathrm{mmol})$ was dissolved in concentrated $\mathrm{H}_{2} \mathrm{SO}_{4}(5 \mathrm{~mL})$ with stirring before cooling in ice to approximately $5^{\circ} \mathrm{C} .65 \% \mathrm{HNO}_{3}(0.16 \mathrm{ml})$ dissolved in concentrated $\mathrm{H}_{2} \mathrm{SO}_{4}(1.45 \mathrm{~mL})$ was then added drop-wise at a rate that kept the reaction temperature close to $0-5^{\circ} \mathrm{C}$, and stirring continued for a further $15 \mathrm{~min}$. The white reaction mixture was then poured slowly onto an ice/water slurry with stirring, and the resulting white solid collected by filtration. The solid was then washed with water and dried in room temperature to afford a white solid. Yield: $0.94 \mathrm{~g}(83 \%)$. (Melting point $\left.=147-150^{\circ} \mathrm{C}\right) .{ }^{1} \mathrm{H} \mathrm{NMR}$ : $(300 \mathrm{MHz}$, $\left.\mathrm{CDCl}_{3}\right): 3.89(\mathrm{~s}, 3 \mathrm{H}), 3.96(\mathrm{~s}, 3 \mathrm{H}), 7.55(\mathrm{~d}, 1 \mathrm{H}), 7.75(\mathrm{~d}, 1 \mathrm{H}), 7.85(\mathrm{~d}, 2 \mathrm{H}), 8.04(\mathrm{~d}, 2 \mathrm{H}), 8.56(\mathrm{~s}, 1 \mathrm{H}) \mathrm{ppm}$. FT-IR (KBr pellet, $\left.\mathrm{cm}^{-1}\right)$ : 2955, 1724, 1535, 1284, 1115, 756, 486.

3.3. Preparation of dimethyl-2-aminobiphenyl-4,4'-dicarboxylate $\left(L_{3}\right)$. To a stirred solution of dimethyl2-nitrobiphenyl-4,4'-dicarboxylate (0.94 g, $2.97 \mathrm{mmol})$ in $37 \mathrm{~mL}$ of methanol tin powder (2 g) and $13 \mathrm{~mL}$ of an aqueous $1 \mathrm{M} \mathrm{HCl}$ solution were added. The suspension was heated to reflux for $2 \mathrm{~h}$ under intense stirring before being poured on to crushed ice. The solution was then basified with aq. $1 \mathrm{M} \mathrm{NaOH}$ solution and the precipitated solids were separated by filtration. The crude product was extracted with warm ethyl acetate. Any remaining insoluble byproducts were removed by filtration. The solvent was removed in room temperature and crude product was obtained. Yield: $0.56 \mathrm{~g}(50 \%)$ of light yellow powder. (Melting point= $\left.163-165^{\circ} \mathrm{C}\right) .{ }^{1} \mathrm{H}$ NMR $\left(300 \mathrm{MHz}, \mathrm{CDCl}_{3}, \mathrm{ppm}\right) \delta=3.97(\mathrm{~s}, 3 \mathrm{H}), 3.93(\mathrm{~s}, 3 \mathrm{H}), 3.89\left(\mathrm{~s}, 2 \mathrm{H},-\mathrm{NH}_{2}\right), 7.19(\mathrm{~d}$, 1H), $7.28(\mathrm{dd}, 1 \mathrm{H}), 7.47$ (d, 1H), 7.70 (d, 2H), 8.06 (d, 2H). FT-IR (KBr pellet, $\left.\mathrm{cm}^{-1}\right)$ : 2920, 2538, 1689, $1423,1292,756,555$.

3.4. Preparation of 2-aminobiphenyl-4,4'-dicarboxylic acid $\left(\boldsymbol{L}_{4}\right)$. A mixture of dimethyl-2 aminobiphenyl4,4'-dicarboxylate (0.68 g, $2.39 \mathrm{mmol}, 1$ equiv.) in $13 \mathrm{~mL}$ of THF and $13.2 \mathrm{~mL}$ of an aqueous $1 \mathrm{M} \mathrm{KOH}$ solution was heated to reflux for $16 \mathrm{~h}$. After cooling to room temperature in air, the THF was removed 
under vacuum and the solution was acidified with aq. $1 \mathrm{M} \mathrm{HCl}$. The resulting precipitate was separated by filtration, washed with water, then methanol and air-dried. Yield: $0.585 \mathrm{~g}(95 \%)$ of yellow powder. ${ }^{1} \mathrm{H}$ NMR (300 MHz, DMSO-d6, ppm) $\delta=5.15$ (s, 2H, -NH2), 7.12 (d, 1H, $J=8.0$ Hz, 6-Ar(NH2)), 7.21 (dd, $1 \mathrm{H}, J=1.4,7.8 \mathrm{~Hz}, 5-\operatorname{Ar}(\mathrm{NH} 2)), 7.41$ (d, 1H, $J=1.6 \mathrm{~Hz}, 3-\operatorname{Ar}(\mathrm{NH} 2)), 7.58$ (d, 2H, $J=8.4 \mathrm{~Hz}, 3^{\prime}, 5^{\prime} / 2^{\prime}$, 6' Ar), 8.02 (d, 2H, $J=8.4 \mathrm{~Hz}, 3^{\prime}, 5^{\prime} / 2$ ', 6'-Ar), 12.83 (bs, 2H, -CO2H); 13C NMR (101 MHz, DMSO-d6, ppm) $\delta=116.7,117.8,128.8,129.2,129.9,130.3,130.7,131.4,143.8,145.9,167.6,168.0$. Other data matched those previously reported for this compound

3.5. Preparation of 2-benzylideneamino-1,1'-biphenylx-4,4'-dicarboxylic acid $\left(L_{5}\right)$. 2-aminobiphenyl4,4'-dicarboxylic acid (0.2 g, $0.78 \mathrm{mmol})$ was dissolved in $10 \mathrm{~mL}$ of DMF and benzaldehyde (237 $\mu \mathrm{L}, 2.34$ mmol) was added and the solution was heated to reflux for $24 \mathrm{~h}$. After cooling to room temperature in air, the DMF was removed under vacuum and the resulting precipitate washed with ethanol. Yield: $0.33 \mathrm{~g}$ ( 80 \%) of white powder. ${ }^{1} \mathrm{H}$ NMR (300 MHz, DMSO-d6, ppm) $\delta=7.50(\mathrm{~d}, 3 \mathrm{H}), 7.62(\mathrm{~d}, 3 \mathrm{H}), 7.75(\mathrm{~s}, 1 \mathrm{H})$, 7.84-7.98 (m, 5H), $8.726(\mathrm{~s}, 1 \mathrm{H}), 13.08$ (s, 2H). FT-IR (KBr pellet, $\left.\mathrm{cm}^{-1}\right)$ : 486, 540, 679, 764, 933, 1103, 1304, 1427, 1705, 2538, 3078.

\subsection{Preparation of 2-naphthalen-1-ylmethyleneamino-1,1'-biphenylx-4,4'-dicarboxylic acid ( $\left.L_{6}\right)$. 2-} aminobiphenyl-4,4'-dicarboxylic acid (0.2 g, $0.78 \mathrm{mmol})$ was dissolved in $10 \mathrm{~mL}$ of DMF and 1Naphthaldehyde ( $0.4 \mathrm{~g}, 2.34 \mathrm{mmol}$ ) was added and the solution was heated to reflux for $24 \mathrm{~h}$. After cooling to room temperature in air, the DMF was removed under vacuum and the resulting precipitate washed with ethanol. Yield: $0.35 \mathrm{~g}$ ( $82 \%$ ) of white powder. ${ }^{1} \mathrm{H}$ NMR (300 MHz, DMSO-d6, ppm) $\delta=7.46$ (t, 2H), 7.51 (t, 2H), $7.61(\mathrm{~m}, 4 \mathrm{H}), 7.86(\mathrm{~s}, 1 \mathrm{H}), 7.96-8.12(\mathrm{~m}, 6 \mathrm{H}), 9.01(\mathrm{~d}, 1 \mathrm{H}), 9.24(\mathrm{~s}, 1 \mathrm{H}), 13.06(\mathrm{~s}, 2 \mathrm{H})$. FT-IR $(\mathrm{KBr}$ pellet, cm-1): 532, 756, 918, 1111, 1304, 1420, 1690, 2530, 2955.

\subsection{Preparation of 2-anthracen-9-ylmethyleneamino-1,1'-biphenylx-4,4'-dicarboxylic acid ( $\left.L_{7}\right)$. 2-} aminobiphenyl-4,4'-dicarboxylic acid $(0.2 \mathrm{~g}, 0.78 \mathrm{mmol})$ was dissolved in $10 \mathrm{~mL}$ of DMF and 9anthraldehyde $(0.5 \mathrm{~g}, 2.34 \mathrm{mmol})$ was added and the solution was heated to reflux for $24 \mathrm{~h}$. After cooling to room temperature in air, the DMF was removed under vacuum and the resulting precipitate washed with ethanol. Yield: $0.6 \mathrm{~g}$ ( $85 \%$ ) of white powder. ${ }^{1} \mathrm{H}$ NMR (300 MHz, DMSO-d6, ppm) $\delta=7.46(\mathrm{t}, 2 \mathrm{H}), 7.54$ $(\mathrm{t}, 2 \mathrm{H}), 7.66(\mathrm{q}, 3 \mathrm{H}), 7.9$ (t, 4H), $8.14(\mathrm{~d}, 2 \mathrm{H}), 8.56(\mathrm{~d}, 2 \mathrm{H}), 8.79(\mathrm{~S}, 1 \mathrm{H}), 9.78(\mathrm{~s}, 1 \mathrm{H}), 13.12(\mathrm{~s}, 2 \mathrm{H})$. FTIR ( $\mathrm{KBr}$ pellet, $\left.\mathrm{cm}^{-1}\right)$ : 540, 725, 879, 1288, 1420, 1690, 1798, 2932.

4. Preparation of aromatic tagged-UiO-67: ${ }^{[\mathrm{S} 3, \mathrm{~s} 4]}$ for benzene tagged-UiO-67, $\mathrm{ZrCl}_{4}(9 \mathrm{mgr}, 0.39 \mathrm{mmol})$, glacial acetic acid $(742 \mu \mathrm{l})$ and $\mathrm{L}_{5}(100 \mathrm{mg}, 0.39 \mathrm{mmol})$ were placed in a scintillation vial with $13 \mathrm{~mL}$ dimethylformamide (DMF). The solids were dispersed via sonication for $\sim 15$ minutes, followed by 
incubation at $120{ }^{\circ} \mathrm{C}$ for $24 \mathrm{~h}$. After cooling, solids were collected by centrifugation at $9500 \mathrm{rpm}$ for $7 \mathrm{~min}$ in a fixed angle rotor, and the solvent was decanted. The solids were washed with DMF $(2 \times 10 \mathrm{~mL})$, followed by soaking in methanol $(\mathrm{MeOH})$ for $3 \mathrm{~d}$, and the solution was exchanged with fresh $\mathrm{MeOH}(10$ $\mathrm{mL}$ ) every $24 \mathrm{~h}$. After $3 \mathrm{~d}$ of soaking, the solids were collected via centrifugation and dried under vacuum (yield: $35 \mathrm{mg}$, $94 \%$ based on $\mathrm{Zr}$ ). The same procedure is used for naphthalene tagged-UiO-67 and anthracene tagged-UiO-67, by using $\mathrm{L}_{6}$ and $\mathrm{L}_{7}$ ((yield: $90 \%$ and $93 \% \%$ based on $\mathrm{Z}$ for naphthalene taggedUiO-67 and anthracene tagged-UiO-67, respectively).

5. Fluorescence Measurements. The fluorescence properties of aromatic-tagged-UiO-67 MOF were measured in an aqueous emulsion containing MOFs using a Perkin Elmer LS45 fluorescence spectrometer at room temperature. In a typical procedure, $5 \mathrm{mg}$ of an activated MOF was grinding down and then dispersed in $5 \mathrm{ml} \mathrm{H}_{2} \mathrm{O}$ and followed by ultrasonication for 15 minutes. Then $5 \mu$ of this emulsion was added to a $2.5 \mathrm{ml}$ of $\mathrm{H}_{2} \mathrm{O}$ in the fluorescent cell. The fluorescence response of MOF against different analysts was considered by titration of this emulsion through addition of 2 to $7 \mu \mathrm{l}$ of the $10^{-4}$ molar solution of the different amino acids, Figures S1-S16. Also LoD and LoQ of anth-UiO-67 MOF sensor is calculated as $17.344 \mathrm{nM}$ and $57.812 \mathrm{nM}$, respectively, Figure S17.

6. Single crystal diffraction studies. For crystal of 2-[(anthracen-9-ylmethylene)-amino]-biphenyl-4,4'dicarboxylic acid dimethyl ester, intensity data were collected using a STOE IPDS-2T diffractometer with graphite monochromated Mo K $\alpha$ radiation $(\lambda) 0.71073(\AA)$. Data were collected in an a series of $\omega$ scans in $1^{\circ}$ oscillations and integrated using the Stöe $\mathrm{X}$-AREA ${ }^{[\mathrm{S} 5]}$ software package. A numerical absorption correction was applied using the X-RED2 ${ }^{[\mathrm{S} 6]}$ and X-SHAPE ${ }^{[\mathrm{S} 7]}$ software's. All structures were solved by direct methods using SHELXS-97 ${ }^{[\mathrm{S} 8]}$ and refined with full-matrix leastsquares on $F^{2}$ using the SHELXL-97 program package. All non-hydrogen atoms were refined anisotropically. Hydrogen atoms were added at ideal positions and constrained to ride on their parent atoms, with $U_{i s o}(\mathrm{H})=1.2$ Ueq. All refinements were performed using the X-STEP32 crystallographic software package. ${ }^{[\mathrm{S} 9]}$ Structural illustrations have been drawn with ORTEP-3 ${ }^{[\mathrm{S} 10]}$ and MERCURY. ${ }^{\left[{ }^{[11]}\right.}$ Crystallographic data for compound 1 have been listed in Table S1.

\section{REFERENCES:}

[S1] Olkhovik, V. K.; Vasilevskii, D. A.; Pap, A. A.; Kalechyts, G. V.; Matveienko, Y. V.; Baran, A. G.; Halinouski, N. A.; Petushok, V. G., ARKIVOC, 2008, 69-93.

[S2] Dau, P. V.; Cohen, S. M., CrystEngComm 2013, 15, 9304-9307. 
[S3] Samanta, P.; Desai, A. V.; Sharma, S.; Chandra, P.; Ghosh, S. K. Inorg. Chem. 2018, 57, 2360-2364.

[S4] Von Zons, T.; Brokmann, L.; Lippke, J.; Preuße, T.; Hülsmann, M.; Schaate, A.; Behrens, P.; Godt, A. Inorg. Chem. 2018, 57, 3348-3359.

[S5] X-AREA: Program for the Acquisition and Analysis of Data, Version 1.30. Stoe \& Cie GmbH: Darmstadt, Germany, 2005.

[S6] X-RED: Program for Data Reduction and Absorption Correction, vesion 1.28b: Stoe \& Cie GmbH: Darmstadt, Germany, 2005.

[S7] X-SHAPE: Program for crystal optimization for numerical absorption correction, vesion 2.05: Stoe \& Cie GmbH: Darmstadt, Germany, 2004.

[S8] Sheldrick, G. M. SHELX-97, Program for the Solution and Refinement of Crystal Structures. Univ. Göttingen, Ger. 1997.

[S9] X-STEP32, Version 1.07 b, Crystallographic Package. Stoe \& Cie GmbH: Darmstadt, Germany, 2000.

[S10] Farrugia, L. J.; IUCr. WinGX and ORTEP for Windows : An Update. J. Appl. Crystallogr. 2012, 45 (4), 849-854.

[S11] Mercury 3.10.1 Supplied with Cambridge Structural Database; CCDC: Cambridge, U.K., 2017-2018. Mercury 3.10.1 Supplied with Cambridge Structural Database; CCDC: Cambridge, U.K., 2017-2018No Title. 

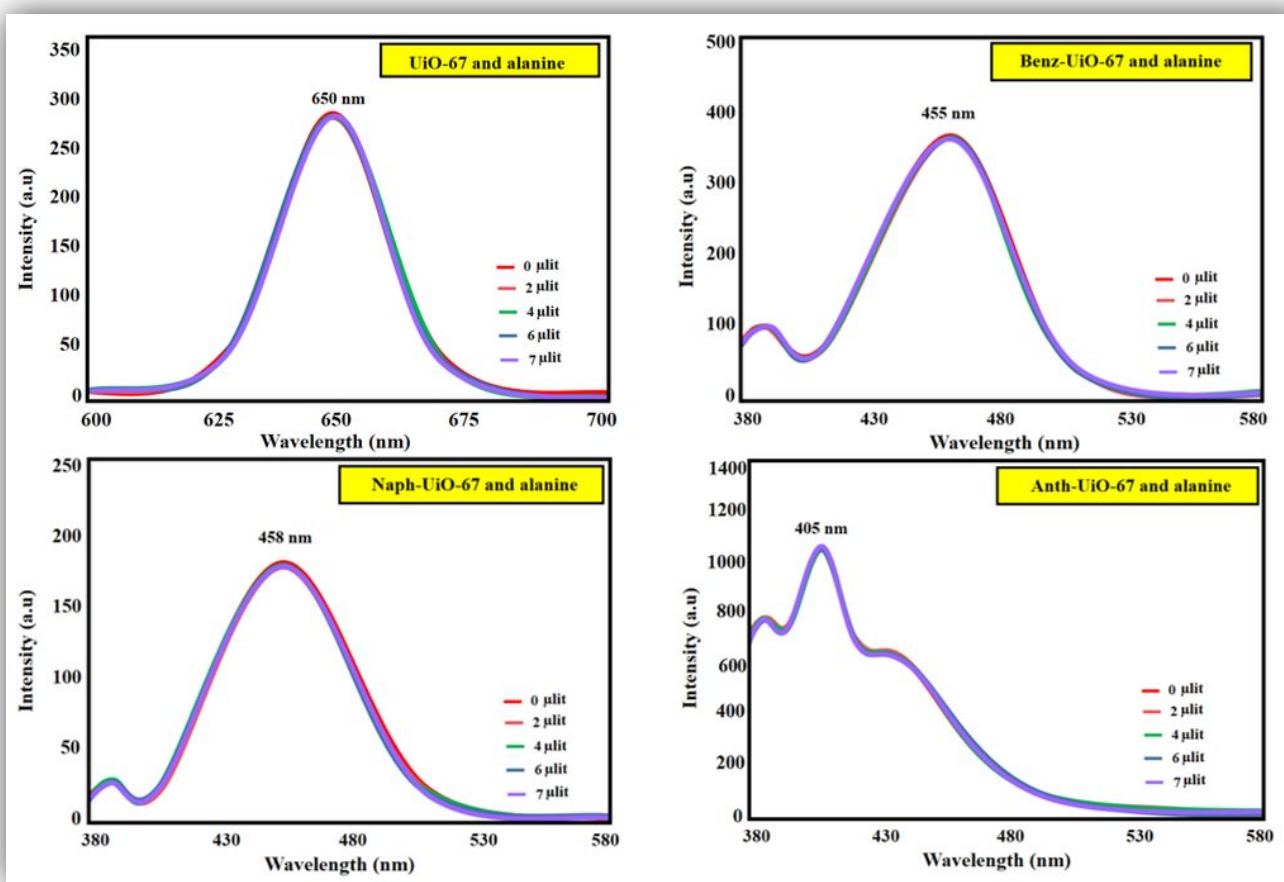

Figure S1. Fluorescence spectral of changes observed for functional aromatic-UiO-67 MOF upon addition of Alanine. 

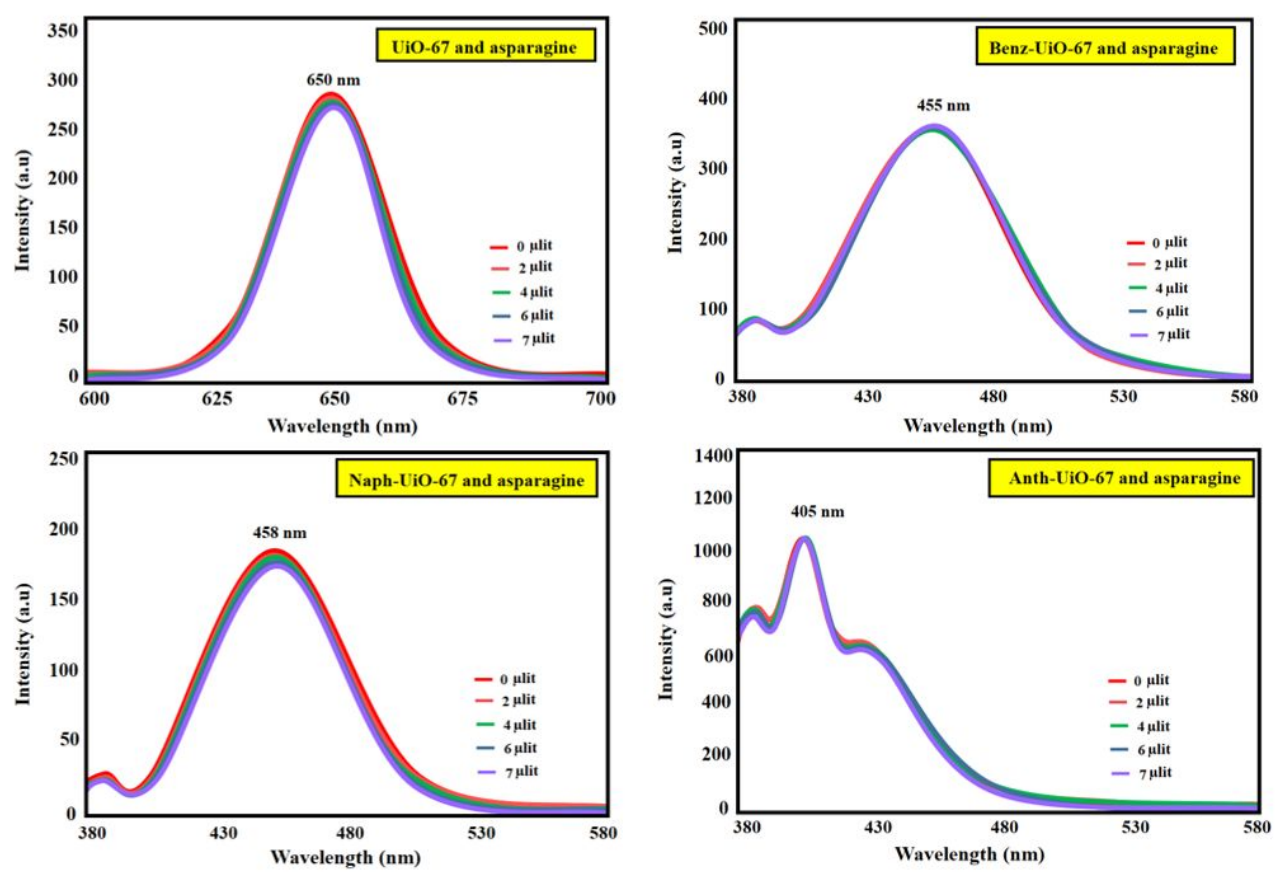

Figure S2. Fluorescence spectral of changes observed for functional aromatic-UiO-67 MOF upon addition of Asparagine. 

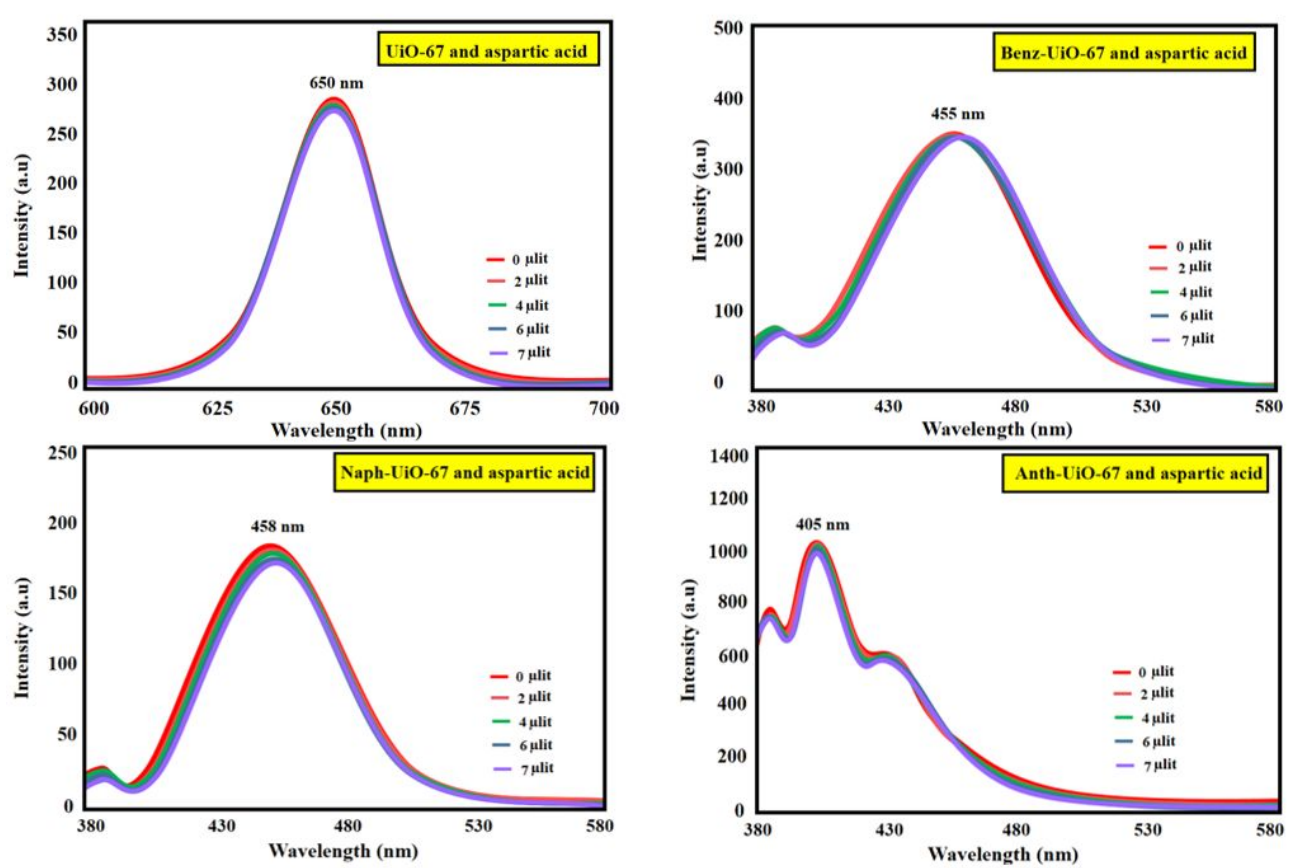

Figure S3. Fluorescence spectral of changes observed for functional aromatic-UiO-67 MOF upon addition of Aspartic acid. 

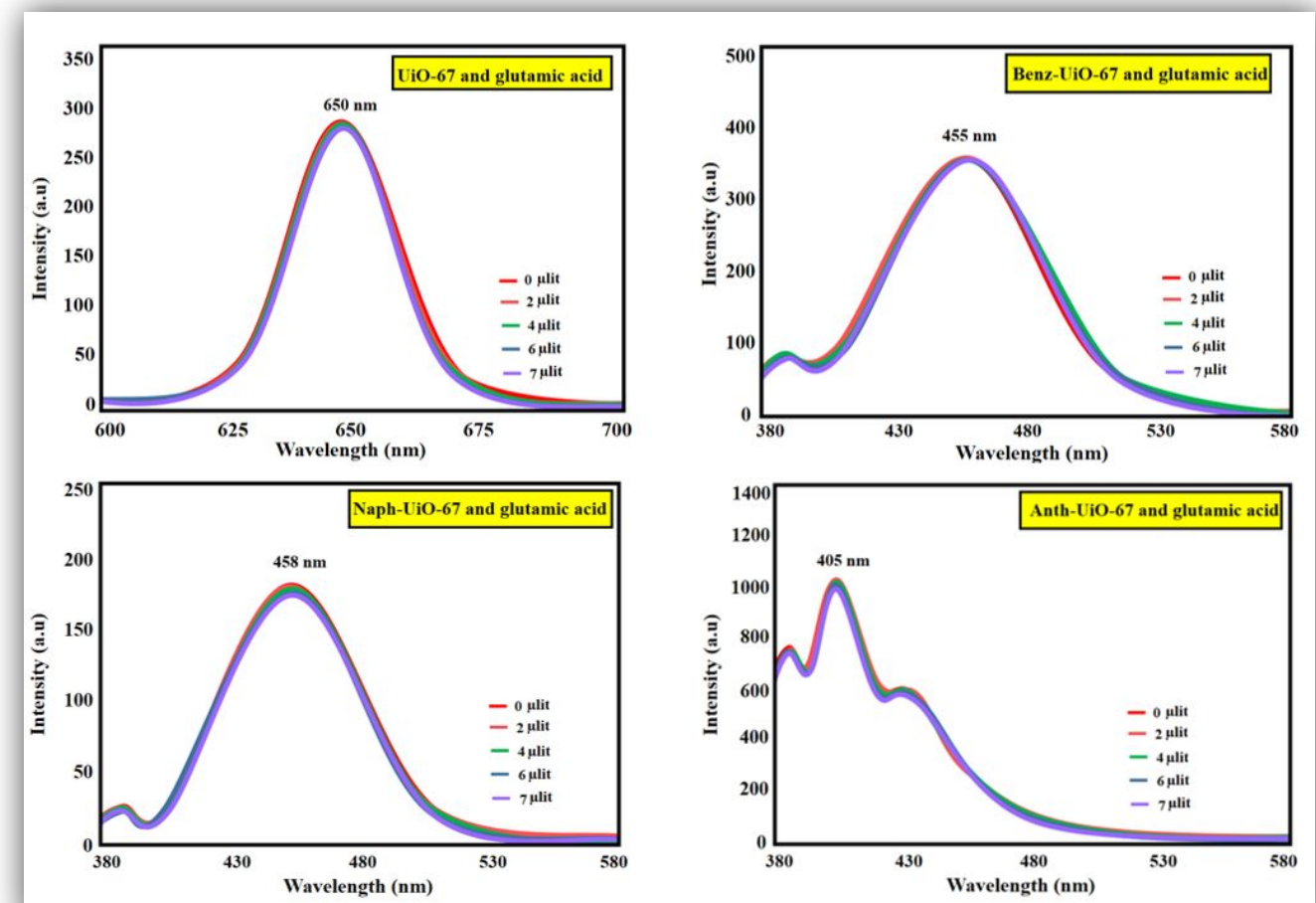

Figure S4. Fluorescence spectral of changes observed for functional aromatic-UiO-67 MOF upon addition of Glutamic acid. 

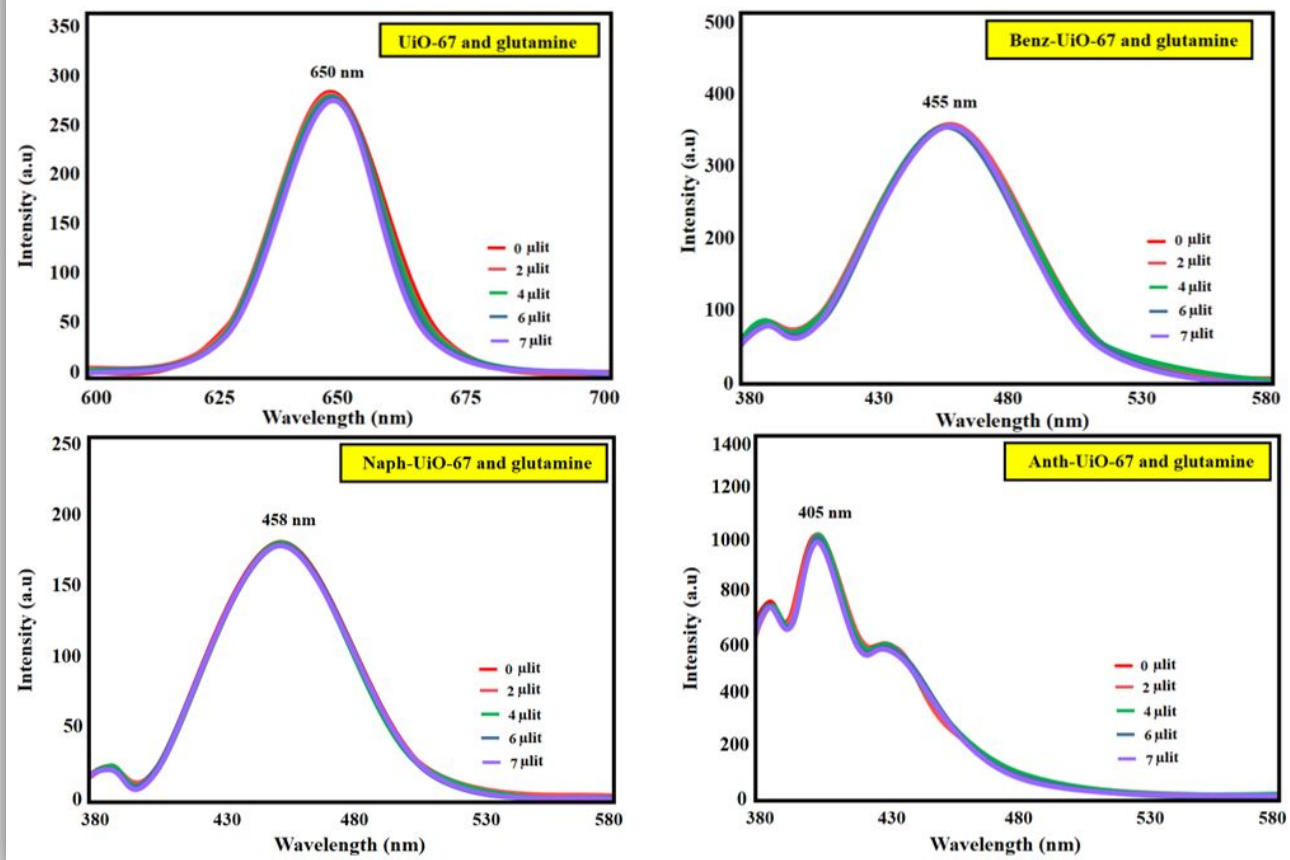

Figure S5. Fluorescence spectral of changes observed for functional aromatic-UiO-67 MOF upon addition of Glutamine. 

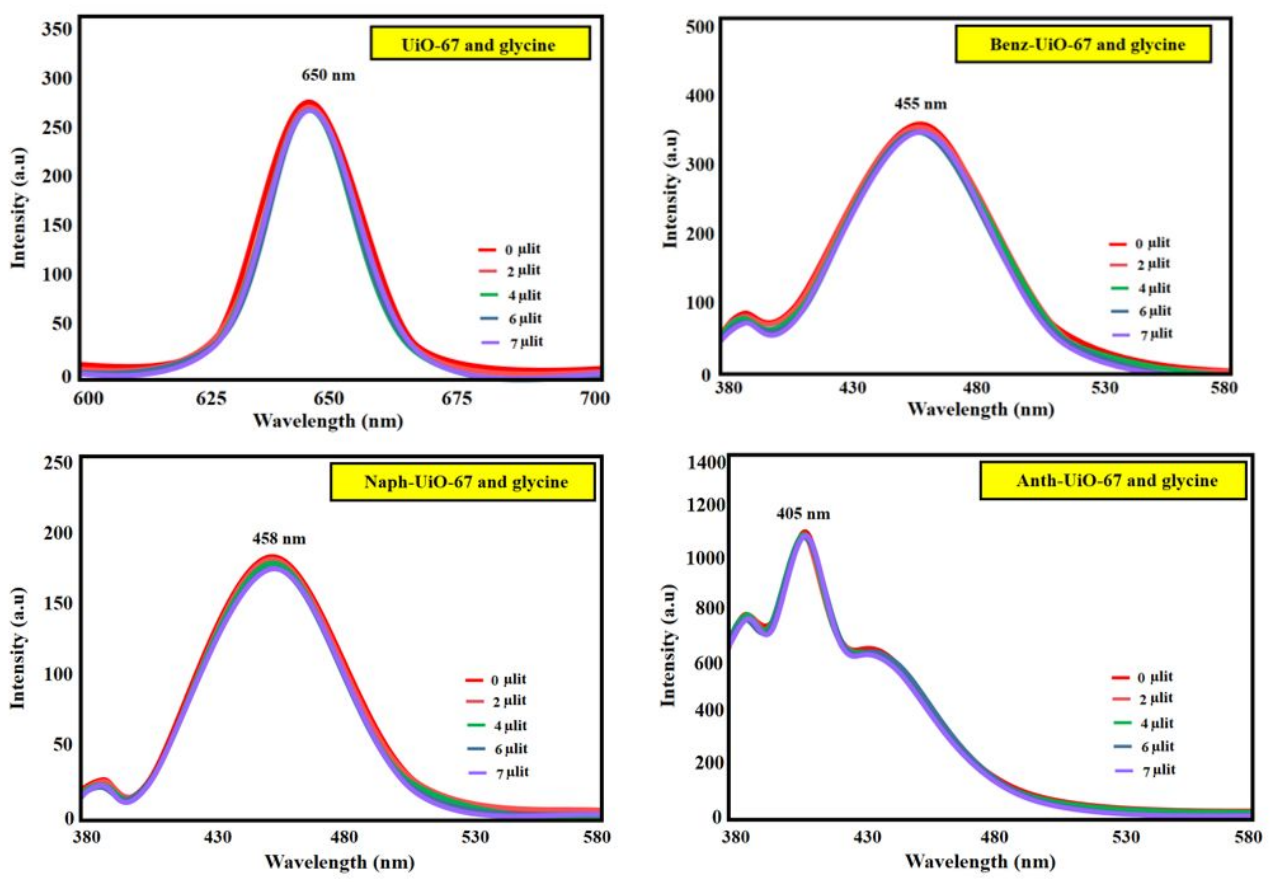

Figure S6. Fluorescence spectral of changes observed for functional aromatic-UiO-67 MOF upon addition of Glycine. 

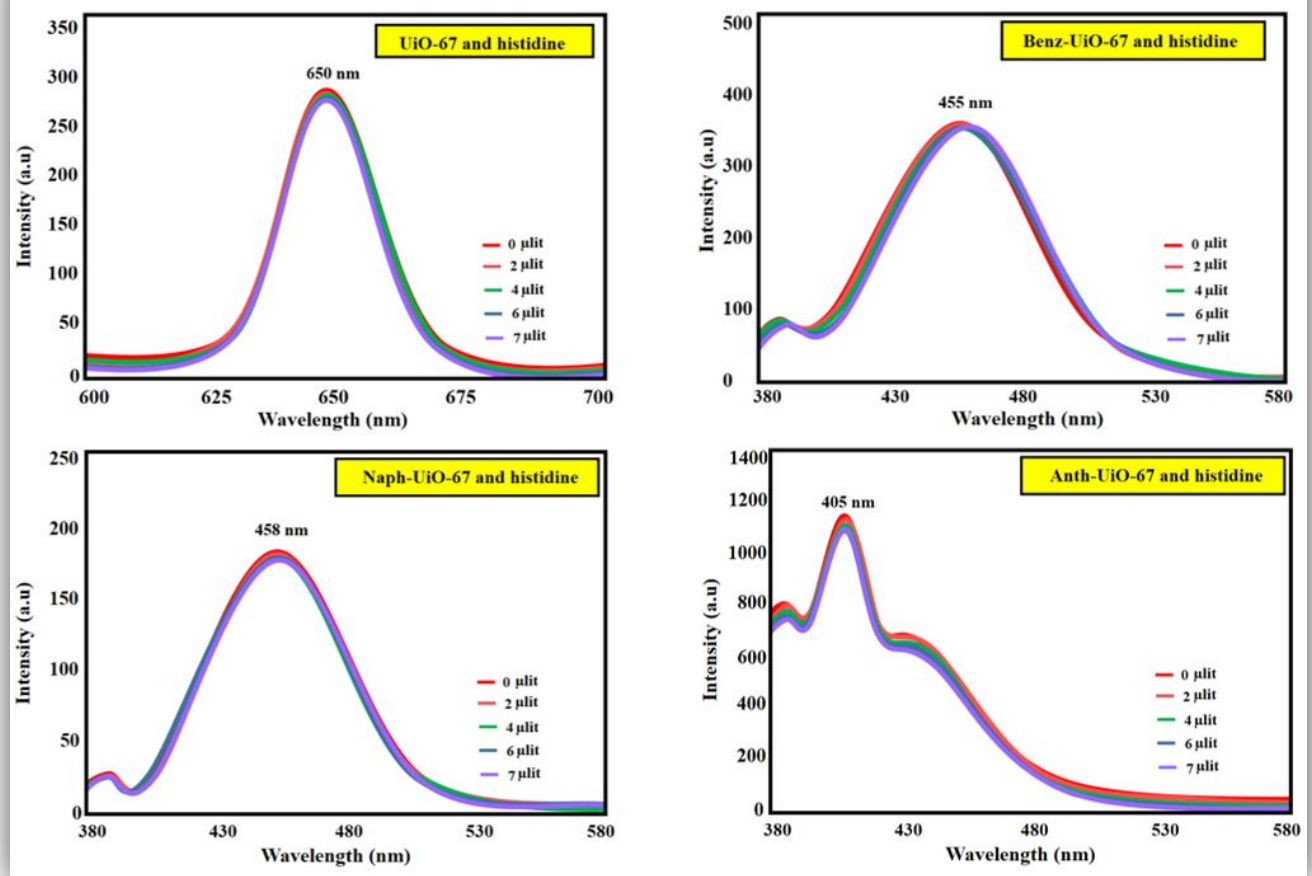

Figure S7. Fluorescence spectral of changes observed for functional aromatic-UiO-67 MOF upon addition of Histidine. 

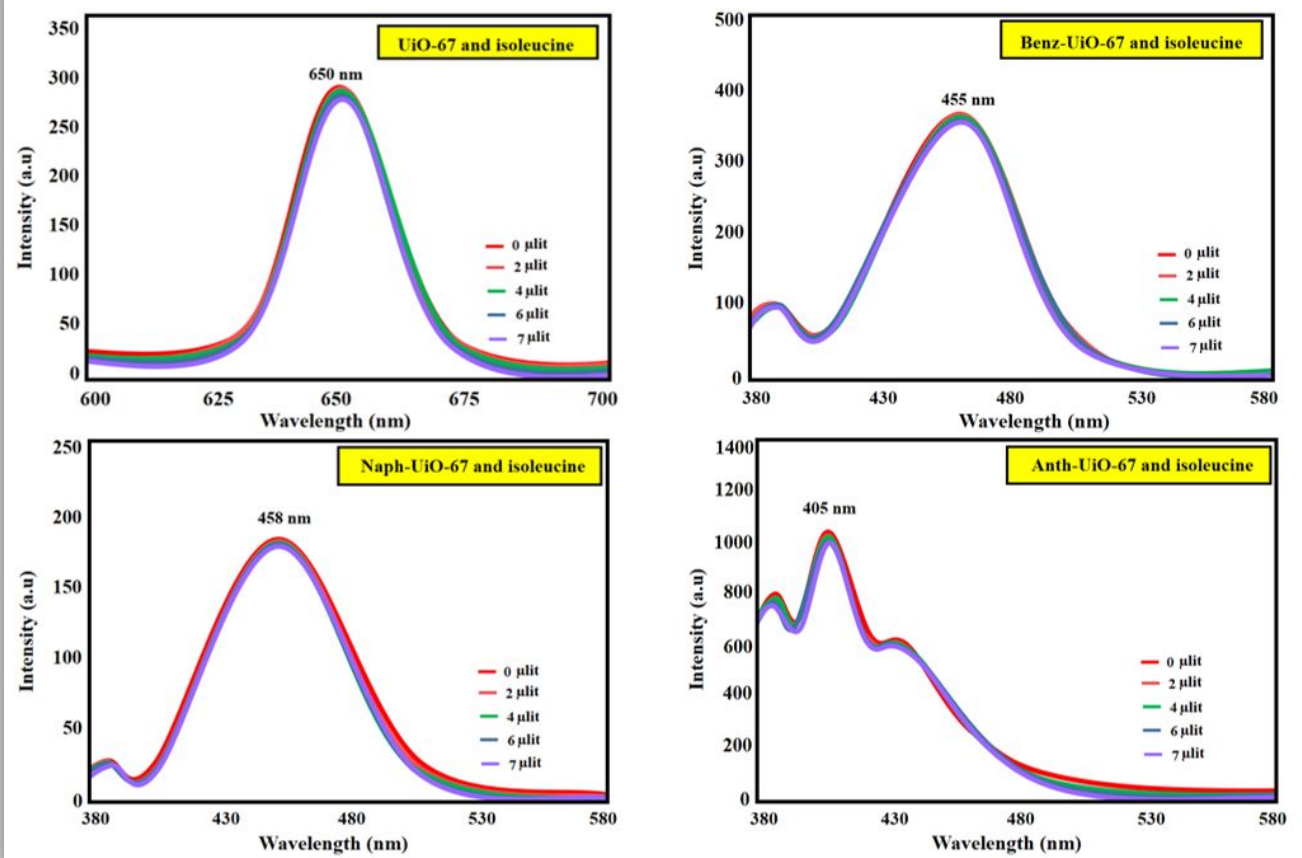

Figure S8. Fluorescence spectral of changes observed for functional aromatic-UiO-67 MOF upon addition of Isoleucine. 

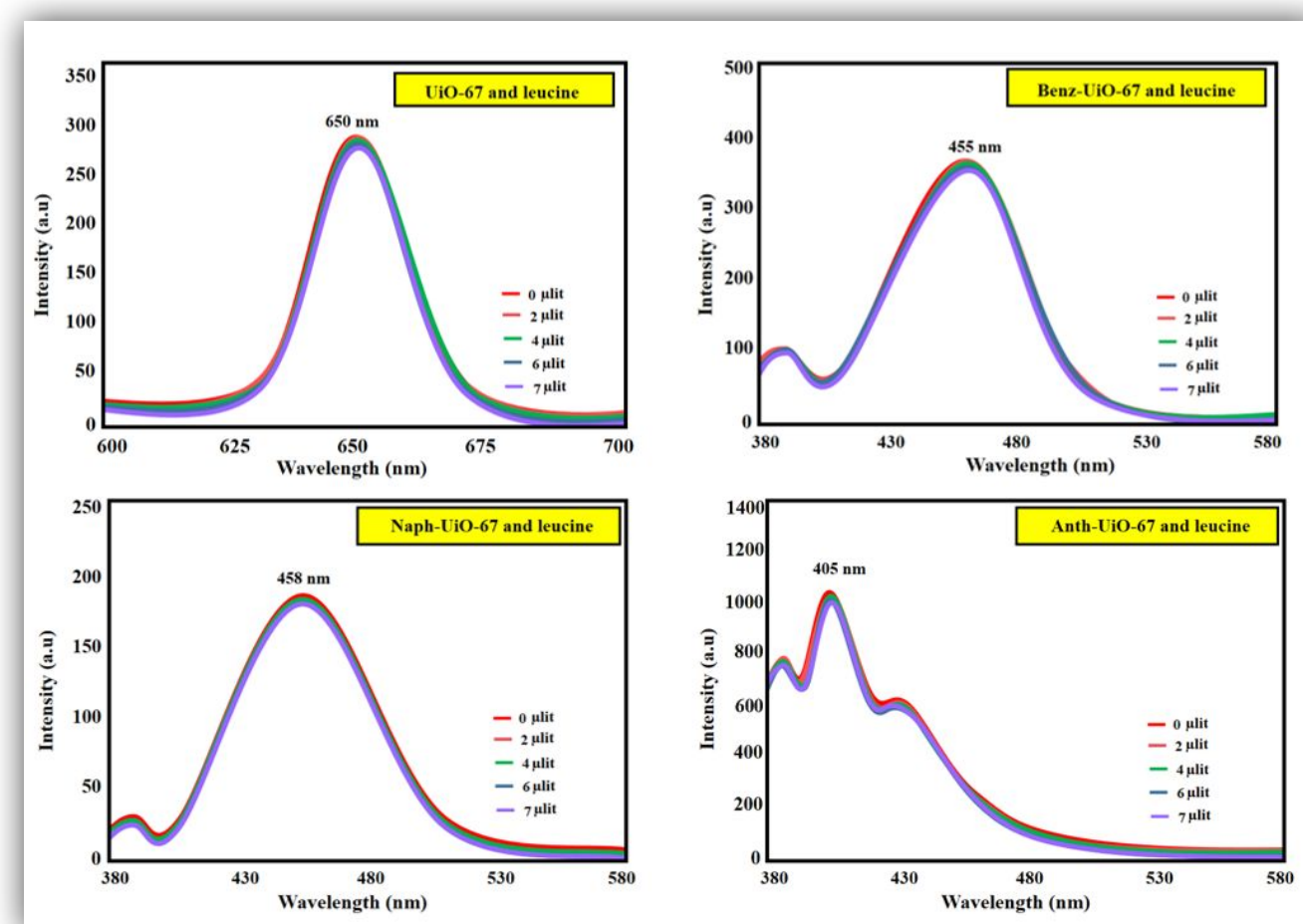

Figure S9. Fluorescence spectral of changes observed for functional aromatic-UiO-67 MOF upon addition of Leucine. 

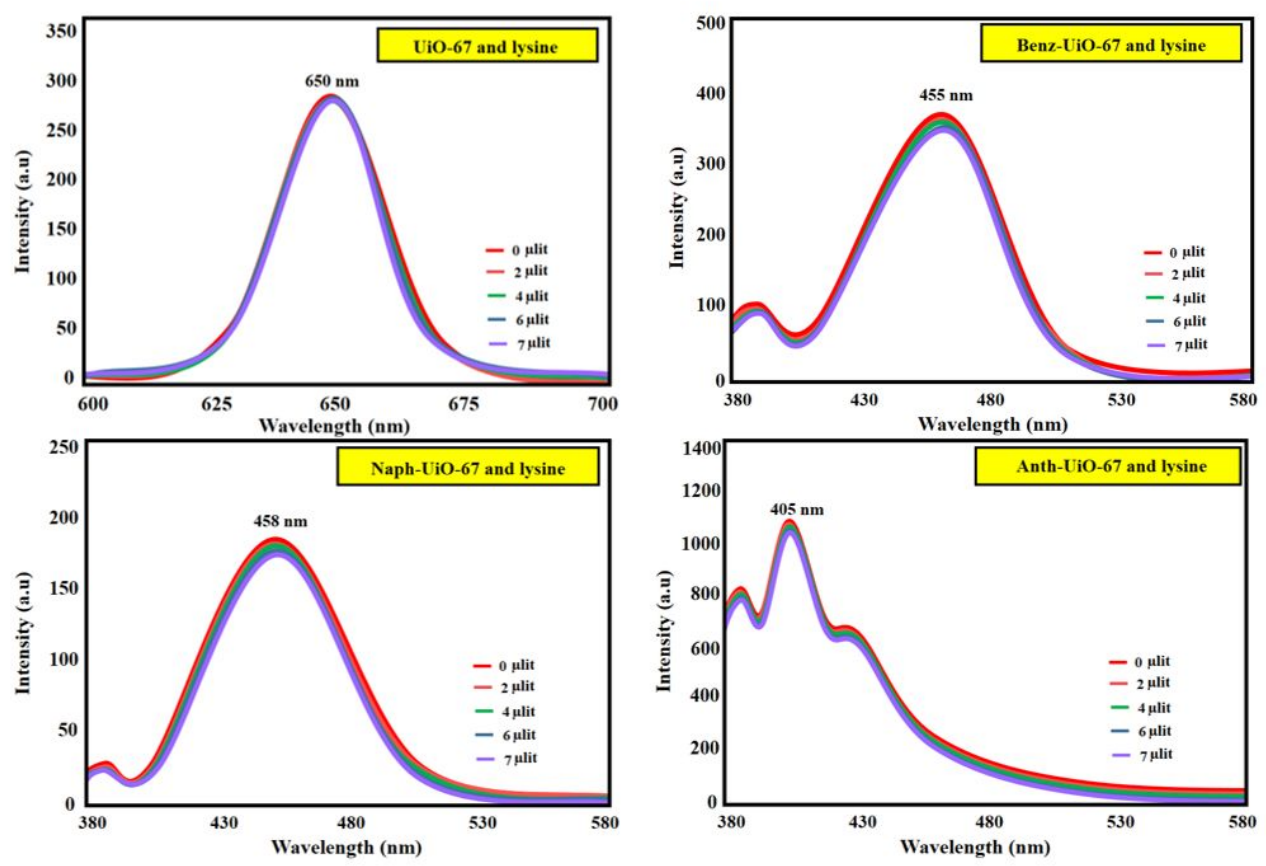

Figure S10. Fluorescence spectral of changes observed for functional aromatic-UiO-67 MOF upon addition of Lysine. 

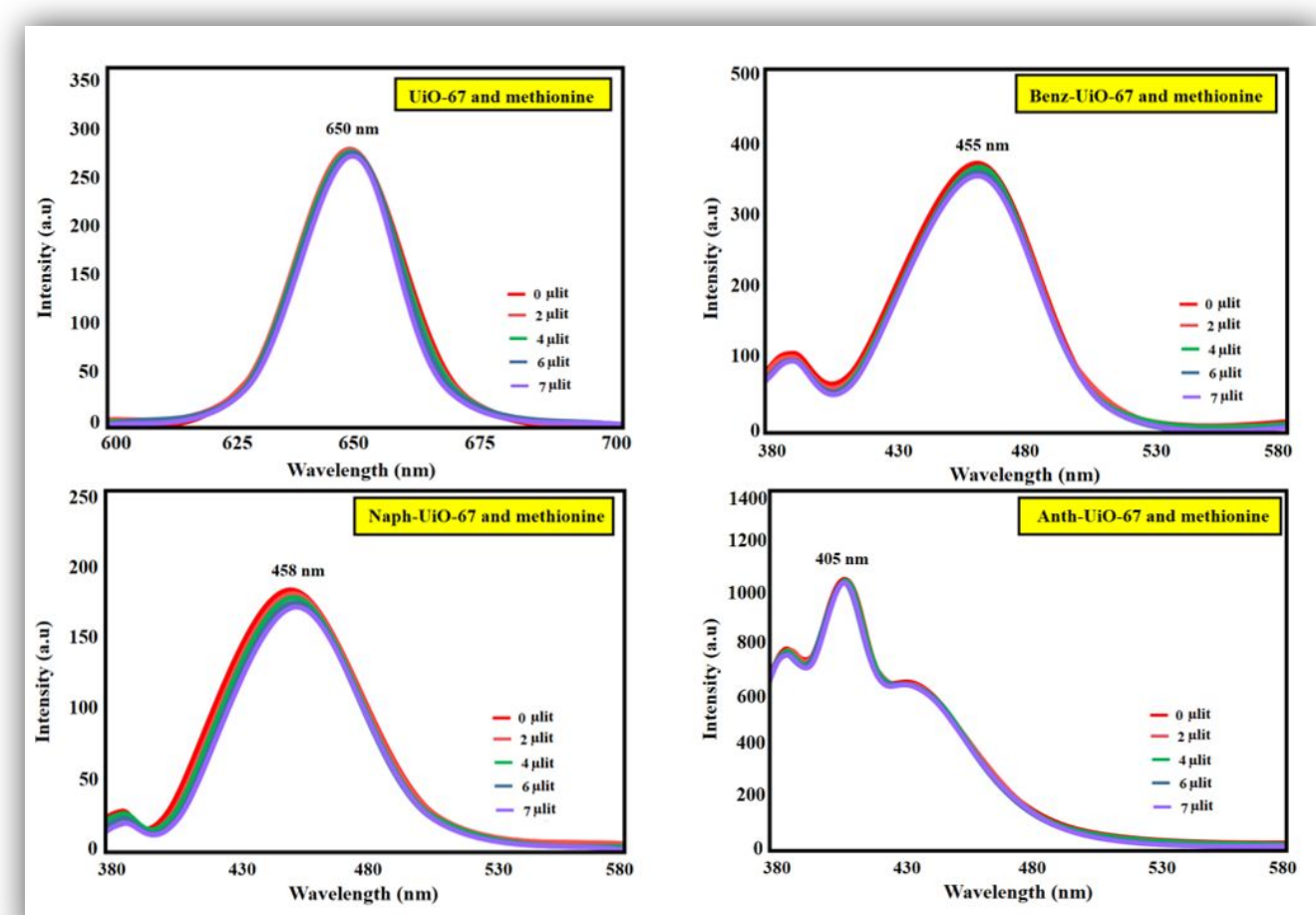

Figure S11. Fluorescence spectral of changes observed for functional aromatic-UiO-67 MOF upon addition of Methionine. 

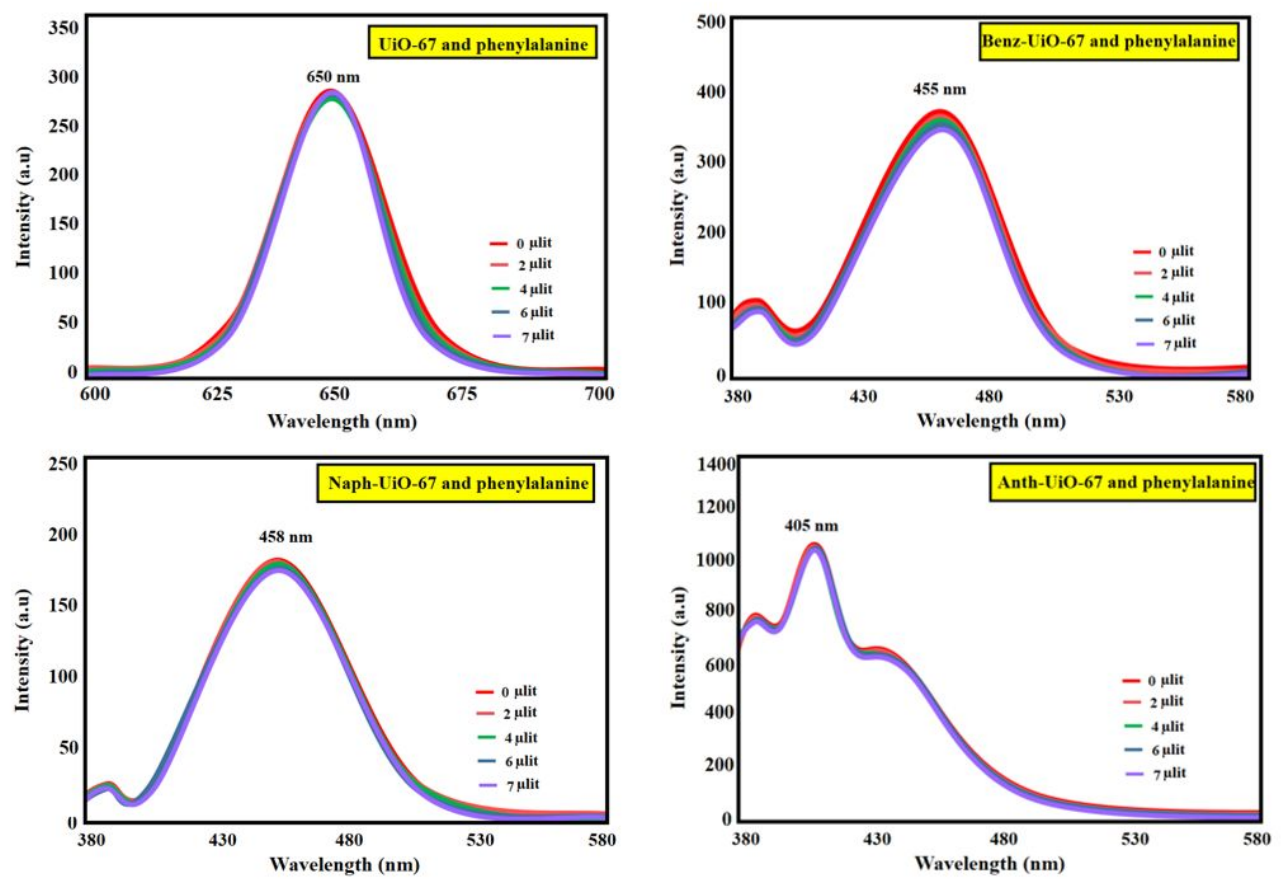

Figure S12. Fluorescence spectral of changes observed for functional aromatic-UiO-67 MOF upon addition of Phenylalanine. 

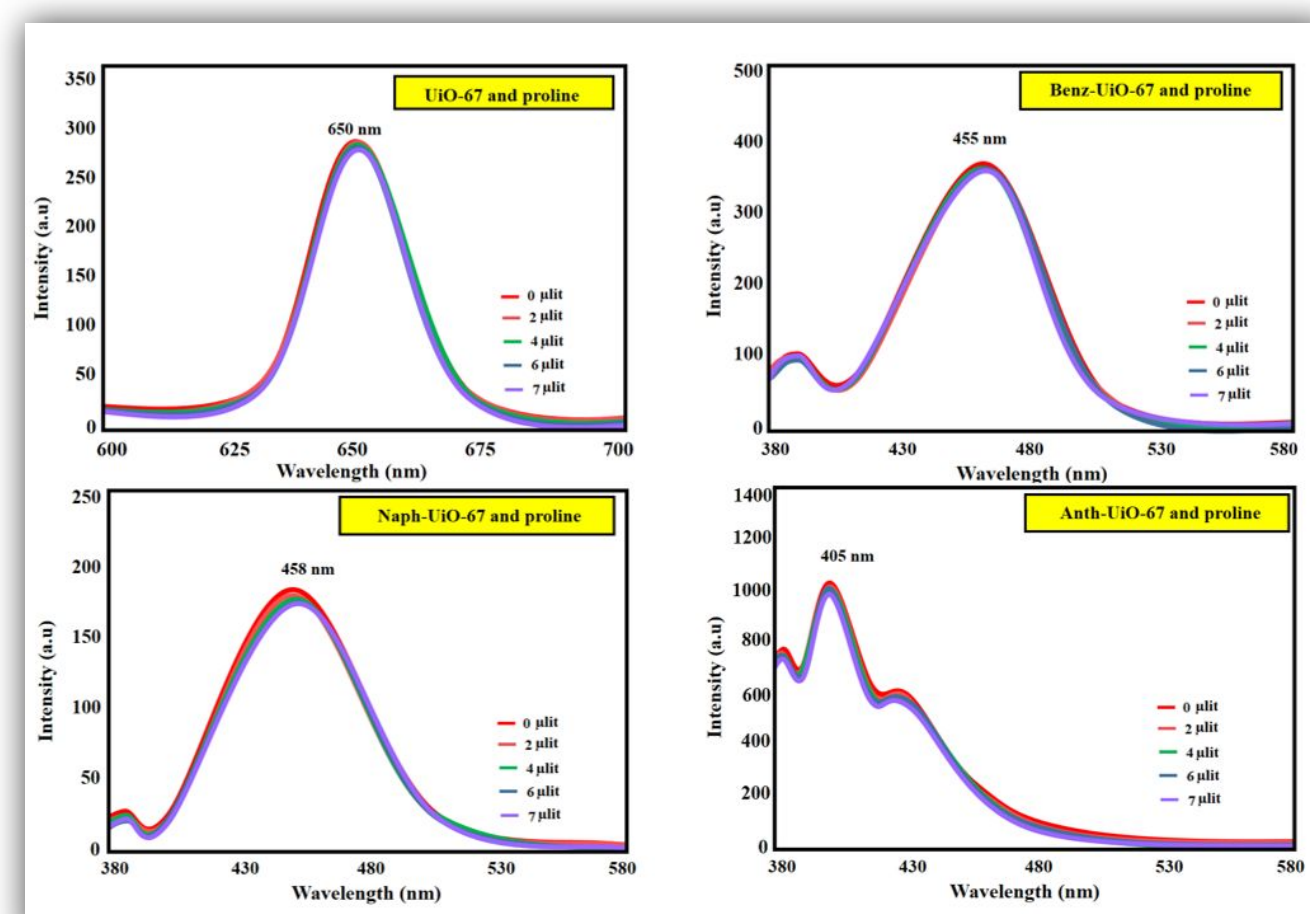

Figure S13. Fluorescence spectral of changes observed for functional aromatic-UiO-67 MOF upon addition of Proline. 

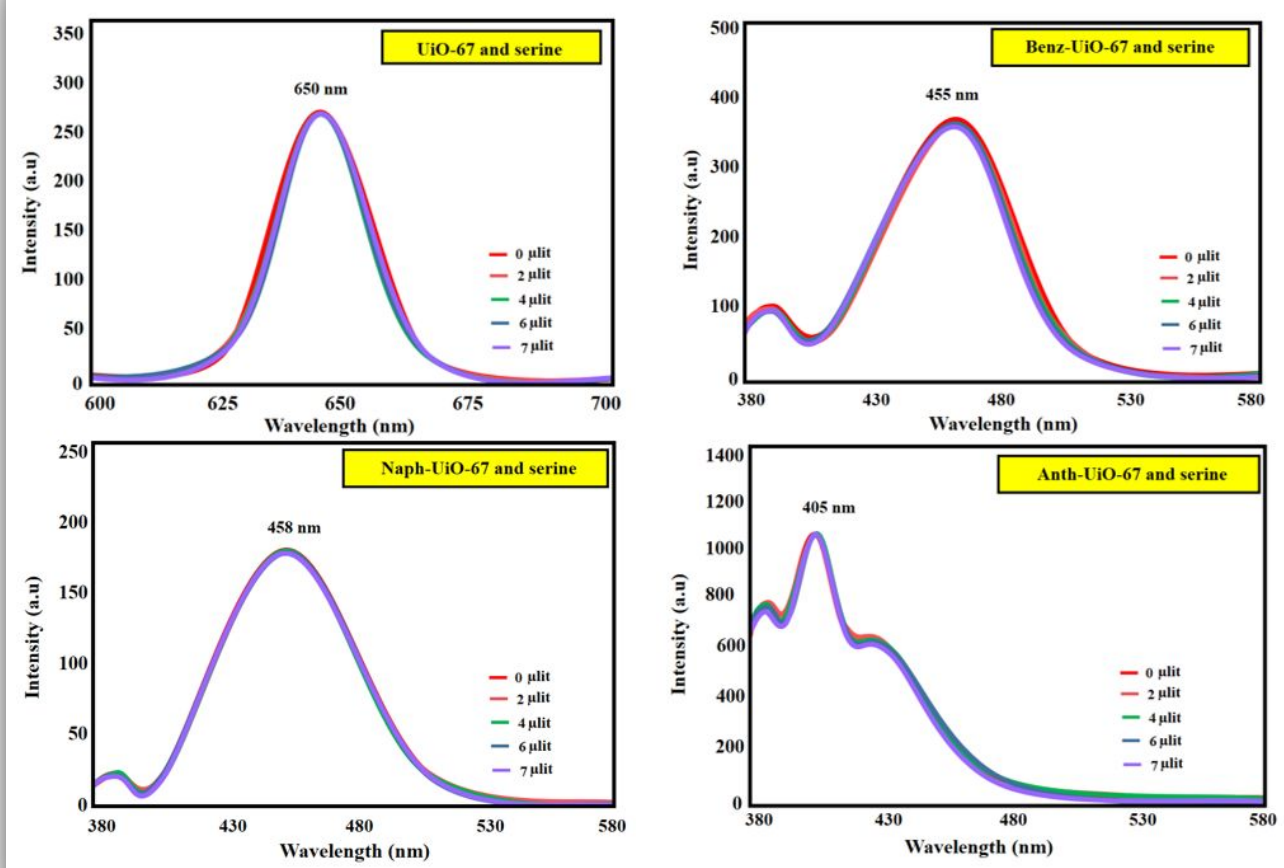

Figure S14. Fluorescence spectral of changes observed for functional aromatic-UiO-67 MOF upon addition of Serine. 

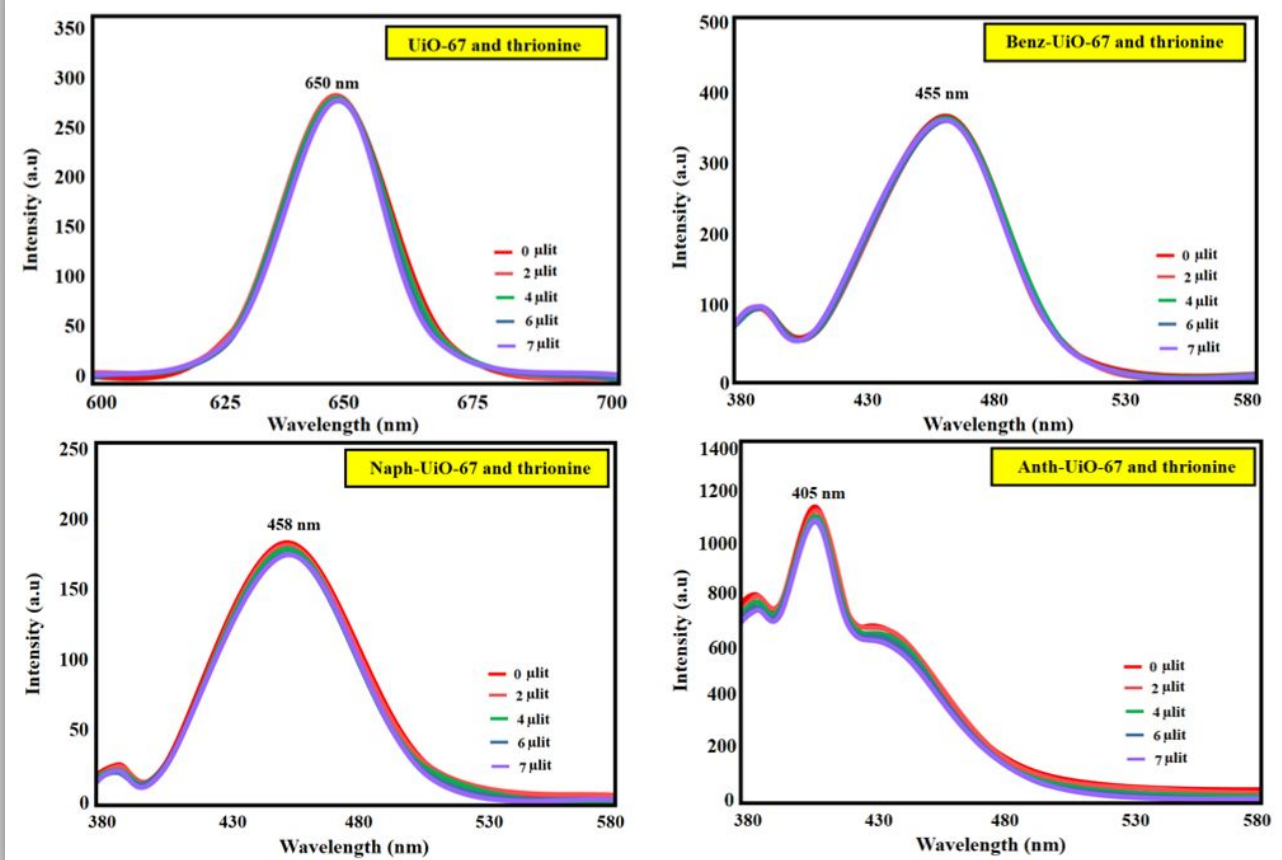

Figure S15. Fluorescence spectral of changes observed for functional aromatic-UiO-67 MOF upon addition of Threonine. 

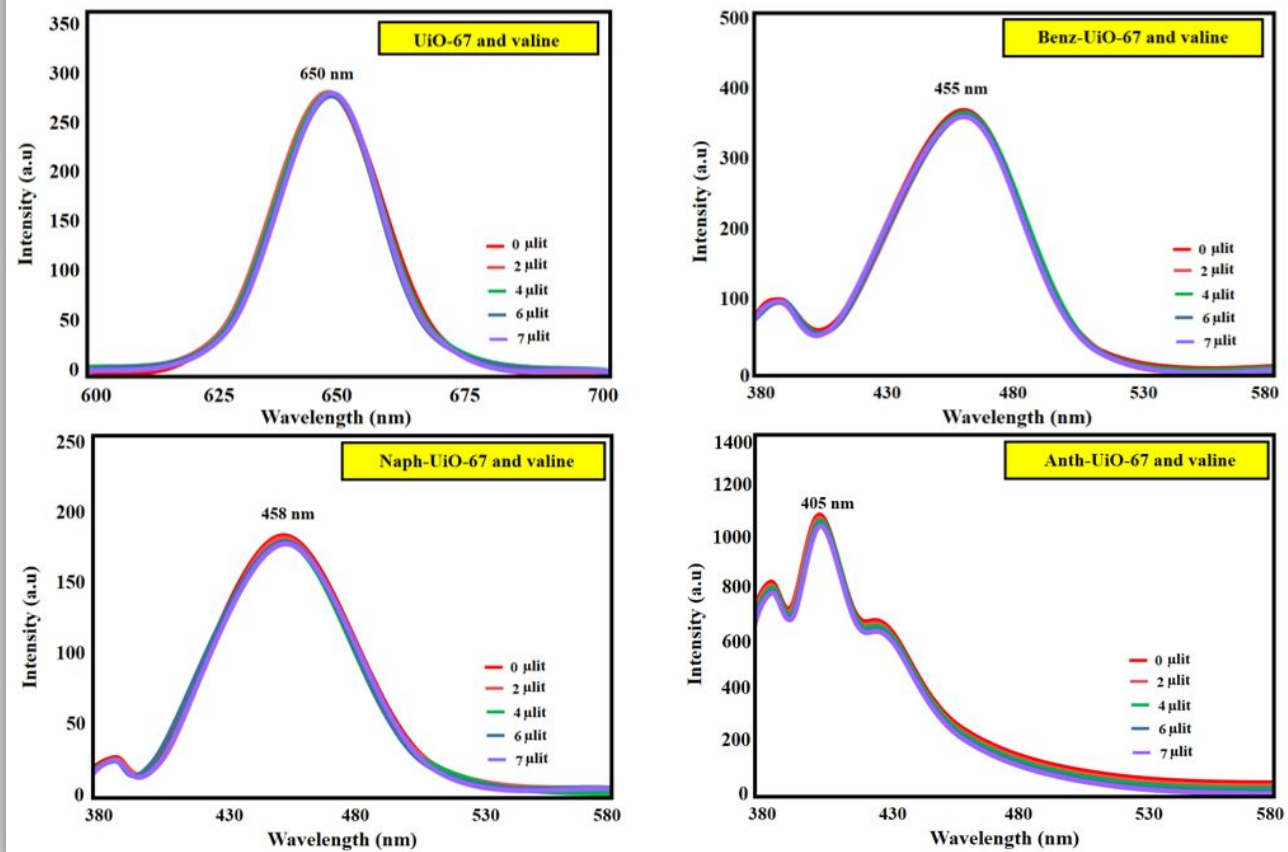

Figure S16. Fluorescence spectral of changes observed for functional aromatic-UiO-67 MOF upon addition of Valine. 


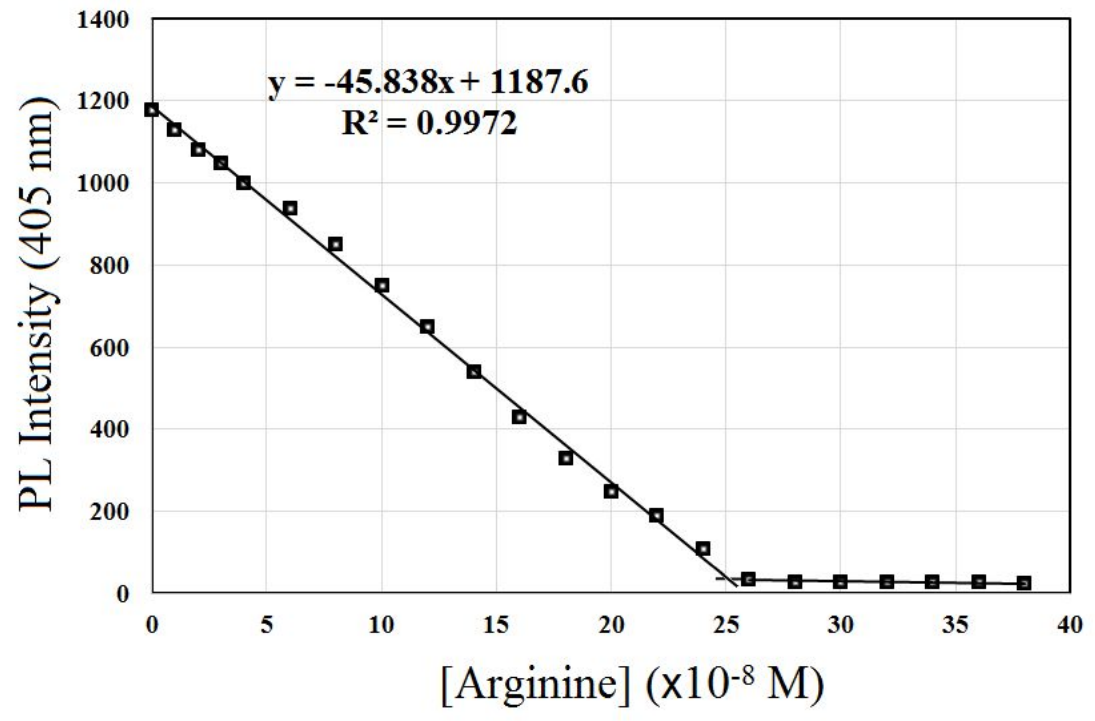

Figure S17. The plot of PL intensity (405 nm) changes of aqueous solution of anth-UiO-67 MOF (5 $\mu$ gr in $2.5 \mathrm{ml} \mathrm{H}_{2} \mathrm{O}$ ) against addition of aqueous solution of arginine amino acid. 
Table S1. Crystal data and structural refinement for 2-[(anthracen-9-ylmethylene)-amino]-biphenyl-4,4'dicarboxylic acid dimethyl ester.

\begin{tabular}{ll}
\hline & compound \\
\hline formula & $\mathrm{C}_{31} \mathrm{H}_{23} \mathrm{NO}_{4}$ \\
fw & 473.50 \\
$\lambda / \AA$ & 0.71073 \\
$T / \mathrm{K}$ & $298(2)$ \\
crystal.system & Triclinic \\
space group & $P^{\overline{1}}$ \\
$a / \AA$ & $9.8305(17)$ \\
$b / \AA$ & $10.1266(16)$ \\
$c / \AA$ & $12.333(2)$ \\
$\alpha /{ }^{\circ}$ & $88.656(13)$ \\
$\beta /{ }^{\circ}$ & $78.440(13)$ \\
$\gamma /{ }^{\circ}$ & $79.948(13)$ \\
$V / \AA^{3}$ & $1184.3(3)$ \\
$\rho_{\text {calc }} \mathrm{g} / \mathrm{cm}^{3}$ & 1.328 \\
$\mathrm{Z}$ & 2 \\
$\mu / \mathrm{mm}^{-1}$ & 0.088 \\
$F(000)$ & 496 \\
$2 \theta /{ }^{\circ}$ & 54.00 \\
$R($ int $)$ & 0.0787 \\
$\mathrm{GOOF}$ & 1.001 \\
$R_{1} \mathrm{a}(I>2 \sigma(I))$ & 0.0521 \\
$\mathrm{w} R_{2} \mathrm{~b}(I>2 \sigma(I))$ & 0.0950 \\
$\mathrm{CCDC} \mathrm{No}$ & 1976227 \\
\hline
\end{tabular}

${ }^{a} R_{1}=\Sigma|| F_{\mathrm{o}}|-| F_{\mathrm{c}}|| \Sigma\left|F_{\mathrm{o}}\right| .{ }^{b} \mathrm{~W} R_{2}=\left[\Sigma\left(\mathrm{w}\left(F_{\mathrm{o}}{ }^{2}-F_{\mathrm{c}}{ }^{2}\right)^{2}\right) / \Sigma \mathrm{w}\left(F_{\mathrm{o}}{ }^{2}\right) 2\right]^{1 / 2}$. 